\title{
Planktivory as a selective force for reproductive synchrony and larval migration
}

\author{
Kevin A. Hovel*, Steven G. Morgan** \\ Marine Sciences Research Center, State University of New York, Stony Brook, New York 11794-5000, USA
}

\begin{abstract}
Diurnally foraging planktivorous fishes are exceptionally dense in marshes worldwide, and larvae of most species of marsh crabs largely may escape predation in time and space by hatching during nocturnal maximum amplitude high tides (NMAHT) when they are rapidly transported to deeper waters under the cover darkness. Species that have long spines or other well-developed larval defenses may be less constrained to release larvae during this safe period. Three species of diurnally foraging planktivorous fishes (Menidia menidia, Fundulus heteroclitus, F. majalis) were very abundant and comprised nearly all of the fishes collected in Flax Pond salt marsh in New York, USA, during the summer of 1994. Four species of crabs (Sesarma reticulatum, Uca pugnax, U. pugilator, Dyspanopeus sayi) also were abundant there and released larvae from mid June to September. These crabs did not release larvae randomly, rather larval release peaked during NMAHT when strong ebb tides transported $97.7 \%$ of the larvae from the marsh by the following day. Larvae that were released during nocturnal minimum amplitude high tides were transported from the marsh less effectively $(84.5 \%$ ). Only $0.37 \%$ of larvae remained in the marsh following the molt to the second instar. Larval release by $D$. sayi was weakly synchronized with the tidal amplitude cycle, and these larvae were transported from the marsh least effectively. Although D. sayi larvae that were released during NMAHT were transported from the marsh nearly as effectively as were the other species $(95.6 \%$ vs $98.0 \%$ of $S$. reticulatum and $99.9 \%$ of Uca spp.). more of them were released near nocturnal minimum amplitude high tide when transport was least effective ( $58.2 \%$ vs $86.0 \%$ of $S$. reticulatum and $87.5 \%$ of Uca spp.). Transport of $D$. sayi larvae from the marsh may have been slowed further by the tidal vertical migrations undertaken by these larvae. In feeding trials conducted in the marsh, M. menidia and $F$. heteroclitus ate about half as many newly released $D$. sayi larvae as $S$. reticulatum and $U$. pugnax larvae $(57.2 \%$ vs $26.1 \%$ of $S$. reticulatum and $32.9 \%$ of $U$. pugnax). Long spines may have deterred predation on $D$. sayi larvae and may reduce selection for rapid transport of these larvae from the marsh. Recruitment to Flax Pond occurred during flood tides, especially strong flood tides, at night when transport to adult habitats was maximal and predation by fishes was minimal. Megalopae of all study species recruited regularly in the same relative proportions that they were released throughout the entire reproductive season, even though larvae of some of the study species (S. reticulatum, D. sayl) likely develop entirely in adjacent Long Island Sound whereas others (Uca spp.) disperse through the sound and onto the continental shelf. This suggests that reproductive and larval behaviors largely overcame mortality during the planktonic phase of the life cycle and coupled production to recruitment, regardless of whether or not recruits primarily originated from local populations. Thus, predictable variation in predation by planktivorous fishes exerts strong selective pressure on crabs that release larvae in productive shallow waters, and suites of reproductive and larval behaviors apparently have evolved that favor migration between adult and larval habitats.
\end{abstract}

KEY WORDS: Predation - Crab larvae Hatching Dispersal Migration - Marshes Silversides - Killifish

\section{INTRODUCTION}

- Present address: School of Marine Science, Virginia Institute of Marine Science, College of William and Mary, Gloucester Point, Virginia 23062, USA

*Addressee for correspondence.

E-mail: smorgan@ccmail sunysb.edu
Predation often varies predictably with environmental cycles. Prey may respond to this strong selective force by reproducing and foraging when predation is minimal (Zaret 1980, Ims 1990, McFall-Nagai 1990, 
Morgan \& Christy 1995). Predation may have a particularly strong impact on the timing of reproduction because eggs, larvae and newborns are often more vulnerable to predators than aduits. In the marine environment, predation may be the most frequently cited cause of diel and tidal periodicities in reproduction, and it has been invoked to explain the shared reproductive patterns of marine animals as diverse as coral reef fishes and intertidal crabs (Johannes 1978, Morgan \& Christy 1995). Eggs of reef fishes and larvae of crabs commonly are released during nocturnal maximum amplitude high tides (NMAHT) just before strong ebb tides may transport them rapidly from productive reefs and shorelines where predators abound However, there are exceptions to this common hatching pattern. It logically follows from the predator avoidance hypothesis that these species are less constrained to release eggs and larvae at this time because they are less vulnerable to predators or because other selective factors are more important (Morgan \& Christy 1997). Here, we test the predictions of the predator avoidance hypothesis as they apply to intertidal crabs.

Female crabs carry developing embryos beneath their abdomen and larval release by many species is synchronized endogenously by cues that are associated with light-dark, tidal, tidal amplitude (usually synonymous with the spring-neap cycle) and lunar cycles (DeCoursey 1983, Salmon et al. 1986, Forward 1987, Morgan 1995a). This endogenous timing system may minimize fatal errors in reproduction by enabling females to anticipate and reliably time the release of larvae. Crabs that belong to 7 different families and that live in a variety of shallow water habitats release larvae during NMAHT, which suggests that strong selective pressures favor larval release at this time (Morgan 1995a). Larvae that are released at this time may be transported quickly from shorelines on the ensuing ebb tide during darkness, which may reduce predation, stranding and physiological stress or may facilitate larval settlement (reviewed by Morgan 1995a). However, growing evidence suggests that this common hatching pattern may have arisen primarily in response to predation by planktivorous fishes, which appear to be the most important predators of crab Iarvae (Morgan 1990, 1992, 1995a, Morgan \& Christy 1995, 1997).

Crab larvae that are released along shorelines during NMAHT enter the water column when planktivorous fishes are least likely to be foraging (Hobson \& Chess 1978, Zaret 1980, Lazarro 1987, Morgan 1990) and when maximal ebb currents transport larvae to deeper waters (Christy 1982, Christy \& Stancyk 1982, Morgan 1990). Planktivorous fishes are especially abundant in productive marshes and other shallow water habitats, and rapid dispersal from these areas may reduce predation on crab larvae (reviewed by Morgan 1986, 1990). Crab larvae released during NMAHT do appear to avoid predation in time and space because they are rare or absent in the diets of fishes, even though they may be the most abundant zooplankter in shallow water habitats soon after hatching (DeCoursey 1979, Christy \& Stancyk 1982, Salmon et al. 1986, Morgan 1990). Furthermore, these crab larvae are readily eaten by fishes during feeding trials (Morgan 1987a, 1989, 1990, Morgan \& Christy 1997).

After crab larvae are transported from shorelines by strong ebb tides, most species are carried seaward by currents. Depending on the species, larvae may disperse well offshore by staying in surface currents at night or they may remain in estuaries by staying nearer to the substrate (reviewed by Epifanio 1988, McConaugha 1988, Morgan 1995b). Larvae of estuarine species also may move upstream by undertaking endogenously timed tidal vertical migrations whereby they rise from bottom waters during flood tides and descend during ebb tides (Cronin \& Forward 1979, 1986). Furthermore, larvae may undertake diel vertical migrations that reduce their visibility to planktivorous fishes (Forward 1988, McFall-Ngai 1990, Morgan 1995b). Ontogenetic vertical migrations may occur for some species that remain lower in the water column than they did earlier in development (Sandifer 1975). After molting 2 to 7 times in about 2 to 5 wk depending on the species (Williams 1984), larvae metamorphose to megalopae (postlarvae) and recruit to adult habitats during flood tides at night (reviewed by J. H. Christy \& S. G. Morgan unpubl.). Thus, vertical migrations are cued by factors that are associated with tidal and lightdark cycles, and larvae and megalopae of many species are transported to and from shallow water habitats by residual and tidal currents under the cover of darkness.

Although considerable circumstantial evidence suggests that the timing of larval release and recruitment to adult habitats reduces predation by planktivorous fishes, the flux of larvae and megalopae in shallow waters has not been adequately documented and related to predation by fishes there. For the predator avoidance hypothesis to be supported, interspecific differences in larval vulnerabilities to predation should be related to the efficiency of larval dispersal from shallow water habitats where predation is presumably high. In turn, the efficiency of larval dispersal is determined by the timing of larval release and the time spent in ebbing surface waters. Therefore, larvae that are most vulnerable to predation should be released during NMAHT, rise in the water column during ebb tides and avoid well lighted surface waters where they would be most conspicuous. In this study, we determined whether a relationship exists between larval 


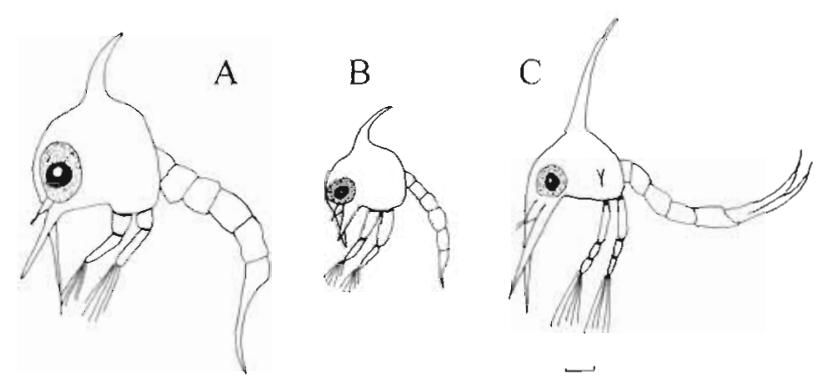

Fig. 1. (A) Sesarma reticulatum, (B) Uca pugnax and (C) Dyspanopeus sayi. Larvae of 3 species of crabs that commonly are released in salt marshes. Scale bar $=0.1 \mathrm{~mm}$

vulnerabilities to predation, reproductive timing and dispersal for crabs living in salt marshes.

The marsh crab Sesarma reticulatum, the fiddler crabs Uca pugnax, U. pugilator and U. minax, and the mud crab Dyspanopeus sayi all release their larvae into shallow marshes along the Atlantic coast of the USA. Differences among larval traits may render some species more vulnerable to predation than others (Fig. 1). Planktivorous fishes generally prefer the most visible and largest manageable prey (O'Brien 1979, Zaret 1980 , Lazarro 1987, Morgan 1990). Morphological traits, such as long spines and large bodies, and antipredatory behaviors, such as spine flaring, make crab larvae more difficult to manage, especially for small gape limited fishes (Morgan 1987a, 1989, 1990), and pigmentation increases the visibility of crab larvae to fishes (Morgan $\&$ Christy 1996). Movement also increases conspicuousness. However, crab larvae swim much more slowly than fishes and do not attempt to evade attacks; rather, they flare antennal spines, remain motionless and rely on armor to survive attacks (Chia et al. 1984, Morgan $1987 \mathrm{a}, 1989$ ). Hence, conspicuously colored, small, short-spined crab larvae generally are more vulnerable to predation than are inconspicuous, large, long-spined larvae, but morphological defenses are most effective at deterring predation by small fishes.

More small short-spined Uca minax larvae were eaten by silversides (Menidia menidia), killifish (Fundulus heteroclitus) and bay anchovy (Anchoa mitchelli) than were large, short-spined Sesarma reticulatum larvae, and large, long-spined Rhithropanopeus harrisii larvae were eaten least often in both laboratory feeding trials and natural populations (Morgan 1987a, 1989, 1990). U. pugnax, U. pugilator and Dyspanopeus sayi larvae are similar morphologically to $U$. minax and $R$. harrisii, and therefore fishes should eat Uca spp., $S$. reticulatum and $D$. sayi larvae in order of decreasing preference. Larvae of all 5 species have brown-black melanophores, and therefore their visibility to fishes should be similar unless larger chromatophores make $S$. reticulatum larvae more conspicuous. The relative importance of spines, body size and pigmentation to the vulnerability of larvae to planktivorous fishes irrespective of gape size is summarized in Table 1.

Thus, previous studies indicate that poorly defended Uca spp. larvae and well-defended Dyspanopeus sayi larvae should respectively be eaten most and least often by planktivorous fishes and disperse most and least effectively from marshes. Because dispersal of newly hatched larvae is determined by the timing of larval release and the time spent in ebbing surface waters, larvae of these species are most and least likely to be released during NMAHT, to rise in the water column during ebb tides and to occur in well lighted surface waters.

These predictions were tested by conducting (1) fish predation experiments in the field, (2) reproductive timing studies in both the laboratory and the field, and (3) larval flux studies in the field. Only 1 species of $U_{C a}$ was used in predation experiments and laboratory reproductive timing studies because the larvae and reproductive timing patterns of $U c a$ spp. are similar (Morgan 1995a), and because UCa spp. cannot be distinguished in plankton samples. Hence, reproductive timing and larval flux in the field was determined collectively for Uca spp.

\section{METHODS AND MATERIALS}

Study site and animals. The study was conducted during the summer of 1994 in Flax Pond salt marsh, which is located on the northern shore of Long Island, New York,

Table 1. Larval morphologies, pigments and expected larval vulnerabilities of 5 species of crabs that commonly release larvae in salt marshes

\begin{tabular}{|c|c|c|c|c|c|c|}
\hline \multirow[t]{2}{*}{ Species } & \multirow[t]{2}{*}{ Size } & \multirow{2}{*}{ Spine length } & \multirow[t]{2}{*}{ Pigment } & \multicolumn{3}{|c|}{ Expected vulnerability } \\
\hline & & & & Size & Spine length & Pigment \\
\hline Sesarma reticulatum & Large & Short & Dark & Low & High & High \\
\hline Uca pugnax & Small & Short & Medium & High & High & Low \\
\hline Uca pugilator & Small & Short & Medium & High & High & Low \\
\hline Uca minax & Small & Short & Medium & High & High & Low \\
\hline Dyspanopeus sayi & Medium & Long & Medium & Medium & Low & Low \\
\hline
\end{tabular}




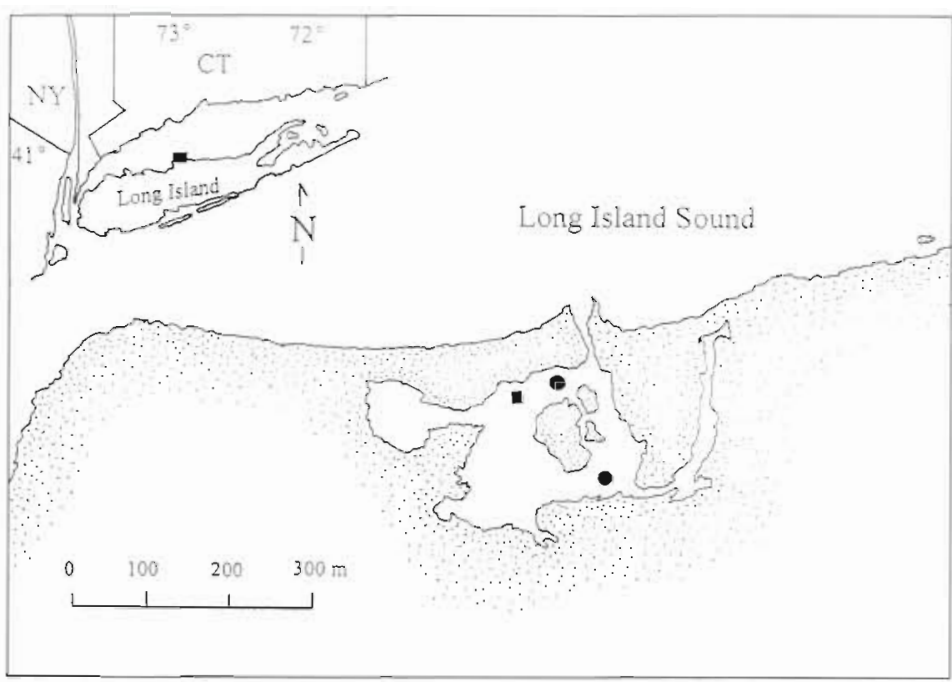

Fig. 2. Study sites in Flax Pond, New York, USA. Circles show seining sites, and the square indicates the location of predation experiments. Collectors were located adjacent to both the predation experiment site and the northern seining site. Plankton was collected along a transect between the inlet and the predation experiment site

USA (Fig. 2). Flax Pond was less than $1 \mathrm{~m}$ deep at high tide, except for a $3 \mathrm{~m}$ deep channel $(10 \mathrm{~m} \times 50 \mathrm{~m})$ that connected the marsh with Long Island Sound. Tidal currents flowed through the channel and flushed the marsh during each tidal cycle (Woodwell \& Pecan 1973).

Four species of crabs were abundant in Flax Pond: Sesarma reticulatum, Uca pugnax, U. pugilator and Dyspanopeus sayi. Adults of $D$. sayi ranged from the subtidal to the low intertidal zones, U. pugnax occurred from the low to the middle intertidal zone, and $S$. reticulatum and $U$. pugilator occurred from the middle to the high intertidal intertidal zone of the marsh. Ovigerous females of 3 species (S. reticulatum, U. pug$n a x, D$. sayi) were collected for predation experiments and laboratory reproductive timing studies. Ovigerous females of $S$. reticulatum and $U$. pugnax were collected by digging their burrows, and ovigerous $D$. sayi were collected by overturning rocks during low tides. $U$. pugilator females occasionally were dug from burrows to observe their reproductive condition but were not collected for experiments.

Three species of fishes were common in Flax Pond: 1 silverside (Menidia menidia) and 2 killifishes (Fundulus heteroclitus, $F$. majalis). $M$. menida and $F$. heteroclitus were seined from Flax Pond at high tide for predation experiments.

Predation experiments. Ovigerous Sesarma reticulatum, Uca pugnax and Dyspanopeus sayi were held in culture dishes that contained approximately $600 \mathrm{ml}$ of 30 psu seawater, and they were maintained in an incubator at $22^{\circ} \mathrm{C}$ and a $14 \mathrm{~h}$ light: $10 \mathrm{~h}$ dark cycle. Culture dishes were checked for larvae at dawn and dusk, and only active larvae that were less than $12 \mathrm{~h}$ old were used in feeding trials. Sea water was changed daily, and crabs that released larvae were returned to Flax Pond

Menidia menidia and Fundulus heteroclitus were maintained at a density of about 2 fish $1^{-1}$ in 2 flow-through seawater tables (285 1) at the Flax Pond Marine Laboratory. All fishes were held for at least $5 \mathrm{~d}$ before feeding trials to acclimate them to captivity. Fishes were offered Artemia nauplii for $1 \mathrm{~h}$ each day while the flow of seawater to the tables was interrupted. Fishes were not fed the day before feeding trials to standardize hunger levels. The evening before an experiment, 1 fish was placed in each of 10 clear glass carboys (19 l) that contained $153 \mu \mathrm{m}$ filtered water from Flax Pond to acclimate them to field conditions overnight. Five carboys were suspended $0.25 \mathrm{~m}$ below the surface and the other 5 were suspended $2.5 \mathrm{~m}$ deep from a $25 \mathrm{~m}$ long buoy line that was anchored in $3 \mathrm{~m}$ of water (Fig. 2).

On the day of the experiment, 200 crab larvae of each species (600 total) and Artemia nauplii were added to each carboy. Fish were allowed to feed for $3 \mathrm{~h}$ from late morning to early afternoon, and ambient light was measured at 0.25 and $2.5 \mathrm{~m}$ midway during each feeding trial. Remaining crab larvae and Artemia nauplii were sieved ( $153 \mu \mathrm{m}$ mesh), and fish were measured and released. As a control, 600 crab larvae were added to 2 carboys without fish and suspended at $0.25 \mathrm{~m}$ depth. After $3 \mathrm{~h}$, larvae were sieved and counted. All larvae were recovered.

Three different sizes of Menidia menidia ('small', 'medium', and 'large') and 2 different sizes of Fundulus heteroclitus ('small' and 'medium') were used in feeding trials. Size classes were chosen based on the abundance of fishes at the study site and previously determined preferences of fishes for crab larvae (Morgan $1990)$. The mean standard length $(\mathrm{mm} \pm 1 \mathrm{SE})$ of fishes used in experiments, the number of replicates conducted and the ambient light levels are reported in Table 2.

Artemia nauplii were included in feeding trials because fishes in natural populations choose among crab larvae in the midst of alternative prey. Artemia nauplii were used as alternative prey instead of naturally co-occurring copepods because electivities of silversides and killifish for crab larvae are similar regardless of whether Artemia nauplii or copepods serve as alternative prey (Morgan 1990) and because they can be obtained more easily and reliably. The number of Artemia nauplii provided varied with the size and species of fish to ensure that 20 to $80 \%$ of larvae remained 
at the end of feeding trials. Fish that ate too few prey were not included in analyses because they may have been stressed. Fish that ate all of at least 1 prey species were not included because it obscured preferences for larvae. Allowing fish to feed until as much as $80 \%$ of the prey were consumed provided a conservative test for prey preferences, because fish switch to alternative prey as preferred prey decline (Werner \& Hall 1974, O'Brien 1979, Zaret 1980, Lazarro 1987). Preferred crab larvae will be consumed first but the number remaining may not change substantially after fish switch to larvae of the other 2 species.

Peterson \& Renaud (1989) argued that the assumption of independence is violated in prey choice experiments, because the consumption of each species depends on the changing ratios of prey available. If so, routine statistical analysis is inappropriate because suitable parametric and nonparametric tests both assume statistical independence. Their argument may not be limited to prey choice experiments because plankton are patchily distributed. Hence, the ratio of prey will change as foraging proceeds, regardless of whether fish encounter a patch in bottles or in the plankton. Morgan (1989) has shown that the prey selection by silversides and killifishes is similar regardless of whether fish choose from a mixed assemblage of crab larvae or are fed each type of crab larvae in isolation from the others. This suggests that the assumption of independence is not violated in prey choice experiments using these predators and prey, and statistical analysis is appropriate. Therefore, data were $\log _{10}$ transformed and analyzed by a 2-way analysis of variance (ANOVA) to detect interspecific differences in larval survival at the 2 depths.

Timing of larval release in the laboratory. Crabs were collected, held in the laboratory and checked for larval release as described above from July 1 to September 9 . This period nearly encompassed the entire breeding season (which began 2 wk earlier in mid June) of these species in Flax Pond, and it included at least 4 biweekly cycles so that the number of females releasing larvae relative to the tidal amplitude and light-dark cycles could be determined reliably for each species. The number of females releasing larvae relative to the tidal amplitude cycle was analyzed for nonrandomness by calculating Rayleigh's $r$-statistic, and the Watson-Williams test determined whether reproductive timing by the 3 species of crabs differed (Zar 1984).

Abundance in the plankton. Plankton samples were collected during each phase of the tidal cycle for 3 d following 1 maximum amplitude (spring) tide (August 22 to 25) and for $3 \mathrm{~d}$ following 1 minimum amplitude (neap) tide (August 28 to 31 ) to determine the abundance of crab larvae and megalopae relative to light-dark, tidal and tidal amplitude cycles in Flax Pond. Hence, samples were collected 4 times each day during flood and ebb tides in the daytime and nighttime. A storm prevented sampling during nighttime flood tide on August 23. Paired plankton nets $(30 \mathrm{~cm}$ diam., $335 \mu \mathrm{m}$ mesh) were towed near the surface and bottom of the water column along the channel (Fig. 2) to determine the vertical distributions of larvae and megalopae relative to light-dark and tidal cycles. All tows were made against the current at a speed of 1 to 2 knots for 3 min, which was the time required to navigate the deepest part of the channel. A General Oceanics flow meter was suspended in the mouth of 1 net to estimate the volume of water sampled.

Samples were preserved in $10 \%$ formaldehyde, and all crab larvae were counted and staged using a dissecting microscope. Samples were split with a Folsom plankton splitter when crab larvae were abundant. Only first instar larvae and megalopae were common in Flax Pond, and later larval instars subsequently were grouped into a category called 'late stage larvae'. Densities of Sesarma reticulatum, Uca spp. and Dyspanopeus sayi larvae relative to depth and tidal, tidal amplitude, and light-dark cycles were analyzed separately for each species by a 4-way ANOVA. Nonsignificant interaction terms were removed and data were reanalyzed to increase statistical power. Data

Table 2. Menidia menidia and Fundulus heteroclitus. Standard lengths (SL) of 3 size classes of $M$. menidia and 2 size classes of F. heteroclitus, number of replicates and light levels for predation experiments. Size classes were chosen based on the abundance of fishes at the study site and previously determined preferences of fishes for crab larvae (Morgan 1990)

\begin{tabular}{|c|c|c|c|c|c|c|c|c|}
\hline \multirow{2}{*}{ Predator } & \multirow{2}{*}{$\mathrm{SL} \pm 1 \mathrm{SE}(\mathrm{mm})$} & \multicolumn{2}{|c|}{ No. of replicates } & \multicolumn{3}{|c|}{ Irradiance $\left(\mathrm{mW} \mathrm{cm}^{-2}\right)$} & \multicolumn{2}{|c|}{ Percentage of surface irradiance } \\
\hline & & $0.25 \mathrm{~m}$ & $2.5 \mathrm{~m}$ & Surface & $0.25 \mathrm{~m}$ & $2.5 \mathrm{~m}$ & $0.25 \mathrm{~m}$ & $2.5 \mathrm{~m}$ \\
\hline M. menidia & $23.1 \pm 1.4$ & 5 & 5 & 24.20 & 18.11 & 2.66 & 75.03 & 11.02 \\
\hline M. menidia & $34.7 \pm 2.2$ & 7 & 7 & $5.79-23.01$ & $3.77-12.66$ & $0.49-2.01$ & $65.00-72.29$ & $8.50-8.75$ \\
\hline M. menidia & $44.3 \pm 1.7$ & 6 & 7 & $23.94-36.00$ & $16.72-33.04$ & $3.26-7.62$ & $91.10-92.11$ & $14.95-22.99$ \\
\hline F. heteroclitus & $23.9 \pm 1.2$ & 5 & 5 & 4.01 & 3.17 & 0.594 & 79.06 & 14.80 \\
\hline F. heteroclitus & $31.1 \pm 1.2$ & 3 & 5 & 53.12 & 44.36 & 7.42 & 83.52 & 13.97 \\
\hline
\end{tabular}


were $\log _{10}$ transformed when necessary to meet assumptions of the test. In addition, the percentages of larvae exported from Flax Pond during nocturnal spring ebb tides and nocturnal neap ebb tides were compared using the Sheirer-Ray-Hare extension of the Kruskal-Wallis test (Sokal \& Rohlf 1995), because assumptions of ANOVA were not met even after data were transformed.

Timing of recruitment. The timing of recruitment to Flax Pond was determined daily from July 17 to September 23 using passive collectors. Megalopae are thigmotactic and settle on collectors regardless of their competency to metamorphose. The design of the collectors was described in detail by van Montfrans et al. (1995). Briefly, collectors were comprised of a removable sleeve of 'hog's hair' air conditioning filter that was slipped around a PVC tube $(50 \mathrm{~cm}$ long $\times 15 \mathrm{~cm}$ diam.). Four collectors were anchored near the inlet of Flax Pond (Fig. 2) and were floated near the surface in 1 to $2 \mathrm{~m}$ of water. The sleeves were replaced daily and were rinsed repeatedly in fresh water to dislodge megalopae. Megalopae were collected on a sieve and transported to the laboratory for identification and quantification. Settlement of Sesarma reticulatum, UCa spp. and Dyspanopeus sayi megalopae on collectors relative to the tidal amplitude cycle was analyzed for nonrandomness by calculating Rayleigh's $r$-statistic.

Fish assemblage. The species composition, abundance and size of fishes in Flax Pond was determined during August. The composition of the assemblage was expected to differ in channel and marsh habitats during the tidal cycle. Therefore to obtain a representative census of the fish assemblage, fishes were sampled twice near the inlet and twice in shallow marsh habitats (Fig. 2) during 1 high and low tide each. Fishes were grouped into $5 \mathrm{~mm}$ size classes ranging from 10 to $130 \mathrm{~mm}$ SL.

\section{RESULTS}

\section{Predation experiments}

The mean number $( \pm 1$ SE, for all depths and sizes combined) of Sesarma reticulatum (73.1 \pm 12.4$)$ and Uca pugnax (76.7 \pm 8.7 ) larvae that survived exposure to Menidia menidia was less than that of Dyspanopeus sayi $(131.3 \pm 10.2)$, but the preferences of silversides depended on fish length (Fig. 3. Table 3 ). D. sayi larvae survived exposure to small and medium silversides better than to large ones, S. reticulatum larvae survived exposure to small silversides better than to
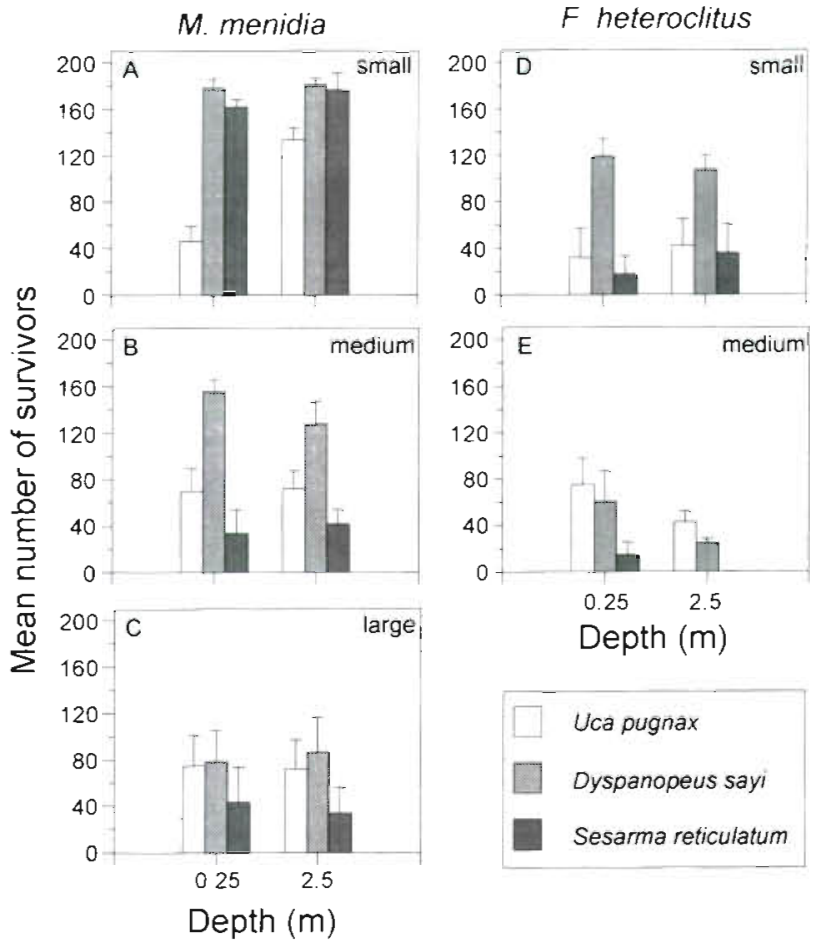

Fig. 3. Sesarma reticulatum, Uca pugnax and Dyspanopeus sayi. Mean number of surviving newly hatched larvae after exposure to (A) small, (B) medium, and (C) large Menidia menidia, and (D) small and ( $E$ ) medium Fundulus heteroclitus in $3 \mathrm{~h}$ long feeding trials in Flax Pond

larger ones, and $U$. pugnax larvae survived poorly when fed to silversides of any size.

Fundulus heteroclitus also preferred larvae of Sesarma reticulatum and Uca pugnax to Dyspanopeus sayi, but unlike silversides, they preferred S. reticulatum to

Table 3. Three-way ANOVA of feeding trials conducted at 0.25 and $2.5 \mathrm{~m}$ depth using crab larvae of 3 species (Sesarma reticulatum, Uca pugnax, Dyspanopeus sayi), 3 size classes of Menidia menidia and 2 size classes of Fundulus heteroclitus in Flax Pond. Data for $F$ heteroclitus feeding trials were $\log _{10}$ transformed. $" p<0.05, \cdots p<0.01, \cdots p<0.001$

\begin{tabular}{|lrrrr|}
\hline Source & df & MS & \multicolumn{1}{c}{ P } \\
\hline Menidia menidia & & & & \\
Depth & 1 & 1292.0 & 0.501 & 0.481 \\
Crab species & 2 & 36700.8 & 14.222 & $<0.001 \cdots$ \\
Fish length & 2 & 60313.0 & 23.371 & $<0.001 \cdots$ \\
Crab species $\times$ Fish length & 4 & 31772.4 & 6.156 & $<0.001 \cdots$ \\
Error & 93 & 2569.4 & & \\
& & & & \\
Fundulus heteroclitus & & & & \\
Depth & 1 & 0.2490 & 1.1495 & 0.289 \\
Crab species & 2 & 7.9650 & 36.7650 & $<0.001 \cdots$ \\
Fish length & 1 & 0.1259 & 0.5809 & 0.450 \\
Crab species $\times$ Fish length & 2 & 0.9909 & 4.5742 & 0.015 \\
Error & 42 & 0.2190 & & \\
\hline
\end{tabular}


U. pugnax larvae (Fig. 3, Table 3). The mean numbers ( $\pm 1 \mathrm{SE}$ ) of $S$. reticulatum, $U$. pugnax and $D$. sayi larvae that survived exposure to killifish were $9.4( \pm 4.8), 43.6$ $( \pm 10.2)$ and $79.9( \pm 11.4)$, respectively. Although the survival of $U$. pugnax and $S$. reticulatum larvae did not vary with fish length, $D$. sayi larvae survived better when they were fed to small rather than medium killifish.

Larval survival of all 3 species combined was greater when larvae were fed to small rather than medium or large silversides, but survival was similar when they were fed to both small and medium killifish (Fig. 3, Table 3). Larval survival was similar when the fishes fed near the surface and bottom of the water column, even though light levels differed significantly (ANOVA, $F=9.88, \mathrm{df}=1,1, \mathrm{p}<0.01$; Table 2). Overall, the mean number $( \pm 1 \mathrm{SE})$ of Sesarma reticulatum $(52.2 \pm 9.4)$ and Uca pugnax $(65.8 \pm 7.0)$ larvae that survived exposure to both fishes was less than that of Dyspanopeus sayi $(114.4 \pm 8.4)$.

\section{Timing of larval release in the laboratory}

All 507 crabs examined released larvae at night, but the timing of larval release relative to the tidal amplitude cycle differed among species (Fig. 4; WatsonWilliams, $F=89.76$, $\mathrm{df}=2,504, \mathrm{p}<0.001 \mathrm{j}$. Larval release by Sesarma reticulatum peaked during maximum amplitude tides $( \pm 2.47 \mathrm{~d}, r=0.54, \mathrm{p}<0.001, \mathrm{n}=$ 61), larval release by Uca pugnax peaked $1 \mathrm{~d}$ before maximum amplitude tides $( \pm 3.19 \mathrm{~d}, r=0.36, \mathrm{p}<0.001$, $\mathrm{n}=173$ ) and larval release by Dyspanopeus sayi peaked $3 \mathrm{~d}$ after maximum amplitude tides $( \pm 3.88 \mathrm{~d}$. $r=0.22, \mathrm{p}<0.001, \mathrm{n}=273$ )

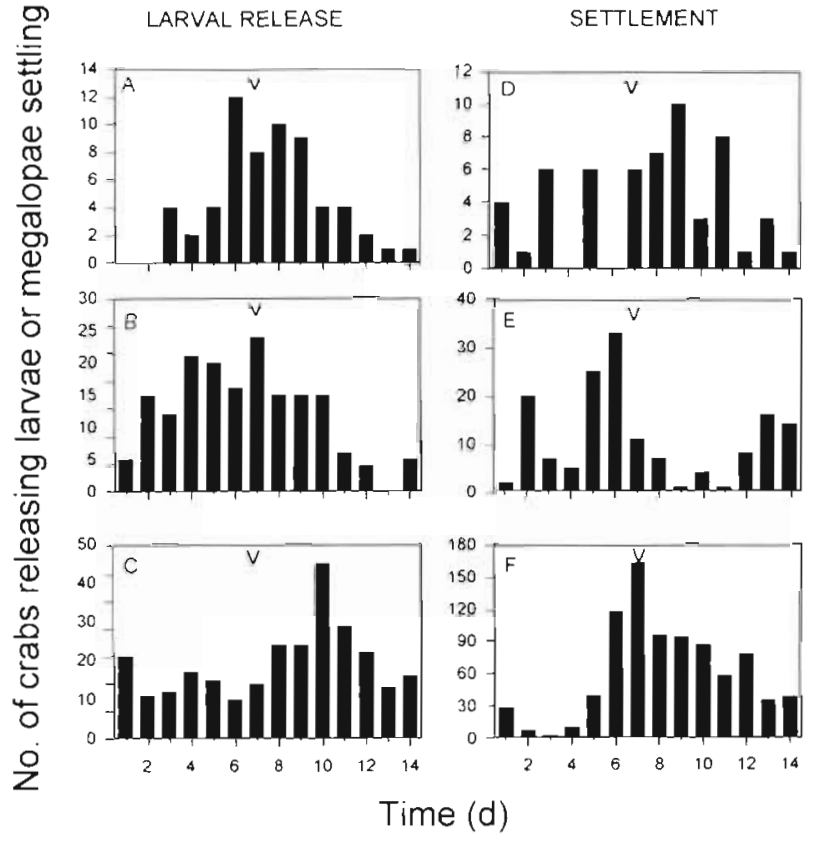

Fig. 4. Total number of (A) Sesarma reticulatum $(\mathrm{n}=61)$, (B) Uca pugnax ( $\mathrm{n}=173$ ) and (C) Dyspanopeus sayi $(\mathrm{n}=273)$ adults releasing larvae from July 1 to September 5, 1994 relative to the $14 \mathrm{~d}$ tidal amplitude cycle, and total number of (D) S. reticulatum $(\mathrm{n}=56)$, (E) U. pugnax $(\mathrm{n}=154)$ and $(\mathrm{F}) D$. sayı $(n=858)$ megalopae settling on collectors from July 17 to September 23, 1994 relative to the 14 d tidal amplitude cycle. Arrows mark the day of spring tides

reticulatum (664), reflecting the relative abundances of adults in Flax Pond. Late stage larvae comprised only $0.2 \%$ of all $S$. reticulatum and Uca spp. larvae in Flax Pond, and late stage $D$. sayi larvae were an order of magnitude $(2.3 \%)$ more abundant than those of the other 2 species.

\section{Abundance in the plankton}

Larvae of 8 species of crabs were caught in plankton tows, and the study species comprised $98.62 \%$ of the larvae collected (Table 4). Of the these species, $99.20 \%$ were first instar larvae, $0.37 \%$ were late stage larvae and $0.43 \%$ were megalopae. Megalopae of Uca spp. $(0.32 \%)$ and Dyspanopeus sayi $(1.8 \%)$ were more abundant than were last stage larvae (UCa spp.: 0.02\%; D. sayi: $0.50 \%$ ). Megalopae of Sesarma reticulatum were not collected in plankton tows. First instar larvae of Uca spp. (96132) were an order of magnitude more abundant than those of D. sayi (7359) and 2 orders more abundant than those of $S$.
Table 4. Abundances of crab larvae and megalopae captured in plankton tows from August 22 to 25 and August 28 to 31, 1994, and abundances of megalopae settling on collectors from July 17 to September 23, 1994, in Flax Pond. Numbers in parentheses are the percentages of the total numbers of larvae and megalopae caught in plankton tows and the percentage of the total number of megalopae settling on collectors

\begin{tabular}{|c|c|c|c|}
\hline \multirow[t]{2}{*}{ Species } & \multicolumn{2}{|c|}{ Plankton } & \multirow{2}{*}{$\begin{array}{l}\text { Collectors } \\
\text { Megalopae }\end{array}$} \\
\hline & Larvae & Megalopae & \\
\hline Uca spp. & $96330(90.87)$ & $306(63.20)$ & $156(14.23)$ \\
\hline Dyspanopeus sayi & $7536(7.11)$ & $142(29.34)$ & $860(78.47)$ \\
\hline Ovalipes ocellatus & $696(0.66)$ & $0(0)$ & $6(0.55)$ \\
\hline Sesarma reticulatum & $683(0.64)$ & $0(0)$ & $56(5.11)$ \\
\hline Libinia emarginata & $560(0.53)$ & $21(4.34)$ & $7(0.64)$ \\
\hline Pinnotheres spp. & $189(0.18)$ & $0(0)$ & $0(0)$ \\
\hline Panopeus herbstii & $12(0.01)$ & $15(3.10)$ & $11(1.00)$ \\
\hline Hemigrapsus sanguineus & $5(<0.01)$ & $0(0)$ & $0(0)$ \\
\hline Total & $106011(100)$ & $484(100)$ & $1096(100)$ \\
\hline
\end{tabular}




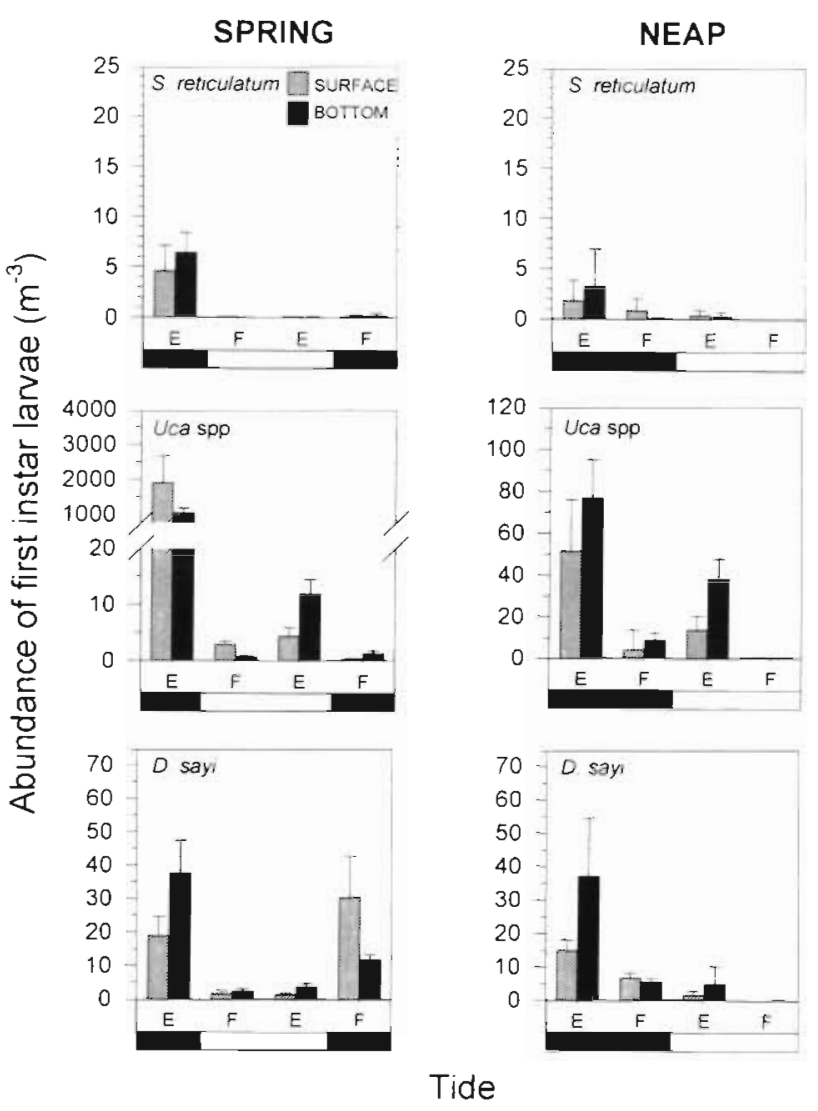

Fig. 5. Sesarma reticulatum, Uca spp. and Dyspanopeus sayi. Mean number $( \pm 1 \mathrm{SE}$ ) of first stage larvae near the surface $(0.25 \mathrm{~m}, \mathrm{n}=6)$ and bottom $(2.5 \mathrm{~m}, \mathrm{n}=6)$ of Flax Pond during $72 \mathrm{~h}$ long plankton surveys conducted during spring (August 22 to 25, 1994) and neap (August 28 to 31, 1994) tides. F: flood; E: ebbi dark bars: night; open bars: day

First instar larvae of Sesarma reticulatum and $U_{C a}$ spp. both tended to be most abundant during nocturnal spring ebb tide (Fig. 5), although this trend was not quite significantly different $(p=0.07)$ for the least abundant study species $S$ reticulatum (Table 5). $S$. reticulatum larvae were significantly more abundant during nocturnal ebb tides than at other times, and they were collected almost exclusively at this time during spring tide suggesting that most of these larvae were exported from Flax Pond. S. reticulatum larvae occurred throughout the water column regardless of light-dark and tidal cycles. Most first stage $U_{C a}$ spp. larvae also should have been flushed from the marsh because they were most common during spring ebb tide at night. Furthermore, they were more abundant during ebb than flood tides in the daytime. Larvae occurred lower in the water column during daytime than nighttime ebb tides, which suggests that they avoided well lighted surface waters while dispersing from Flax Pond.
Table 5. Four-way ANOVA of first instar Sesarma reticulatum, Uca spp. and Dyspanopeus sayi larvae collected in plankton tows relative to the tidal amplitude (Amplitude), tidal (Tide), and light-dark (Diel) cycles at 2 depths (Depth). Data for D. sayı and Uca spp. were $\log _{10}$-transformed. " $\mathrm{p}<$ $0.05, \cdots p<0.01, \cdots p<0.001$

\begin{tabular}{|c|c|c|c|c|}
\hline Source & df & MS & F & $\mathrm{p}$ \\
\hline \multicolumn{5}{|l|}{ Sesarma reticulatum } \\
\hline Amplitude & 1 & 8.97 & 1.67 & 0.200 \\
\hline Tide & 1 & 85.23 & 15.86 & $<0.001 \cdots$ \\
\hline Diel & 1 & 95.78 & 17.83 & $<0.001 \cdots$ \\
\hline Depth & 1 & 0.01 & $<0.01$ & 0.968 \\
\hline Tide $\times$ Diel & 1 & 71.58 & 13.32 & $<0.001 \cdots$ \\
\hline Amplitude $\times$ Tide $\times$ Diel & 1 & 18.27 & 3.40 & 0.069 \\
\hline Error & 76 & 5.37 & & \\
\hline \multicolumn{5}{|l|}{ Uca spp. } \\
\hline Amplitude & 1 & 0.679 & 5.84 & $0.018^{\bullet}$ \\
\hline Tide & 1 & 38.950 & 334.80 & $<0.001 \cdots$ \\
\hline Diel & 1 & 14.660 & 126.00 & $<0.001 \cdots$ \\
\hline Depth & 1 & 0.012 & 0.11 & 0.745 \\
\hline Amplitude $x$ Tide & 1 & 2.676 & 23.00 & $<0.001 \cdots$ \\
\hline Tide $\times$ Depth & 1 & 0.781 & 4.66 & 0.034 \\
\hline Diel $\times$ Depth & 1 & 6.312 & 4.29 & $0.042^{\circ}$ \\
\hline Amplitude $\times$ Diel & 1 & 0.541 & 6.72 & $0.011^{\circ}$ \\
\hline Tide $\times$ Diel & 1 & 0.499 & 54.24 & $<0.001 \cdots$ \\
\hline Amplitude $\times$ Tide $\times$ Diel & 1 & 9.405 & 80.83 & $<0.001 \cdots$ \\
\hline Tide $\times$ Diel $\times$ Depth & 1 & 0.953 & 8.19 & $0.005^{\cdots}$ \\
\hline Error & 76 & 0.116 & & \\
\hline \multicolumn{5}{|l|}{ Dyspanopeus sayi } \\
\hline Amplitude & 1 & 0.9962 & 12.35 & $<0.001 \cdots$ \\
\hline Tide & 1 & 1.4265 & 17.69 & $<0.001 \cdots$ \\
\hline Diel & 1 & 15.3820 & 190.80 & $<0.001 \cdots$ \\
\hline Depth & 1 & 0.3287 & 4.08 & $0.047^{\circ}$ \\
\hline Amplitude $\times$ Tide & 1 & 0.7411 & 9.19 & $0.003 \cdots$ \\
\hline Tide $\times$ Depth & 1 & 0.5929 & 7.35 & $0.008 \cdots$ \\
\hline Diel $\times$ Depth & 1 & 0.4992 & 6.19 & $0.015^{\circ}$ \\
\hline $\begin{array}{l}\text { Amplitude } \times \text { Tide } \times \\
\text { Diel } \times \text { Depth }\end{array}$ & 1 & 0.6312 & 7.83 & $0.006 \cdot$ \\
\hline Error & 76 & 0.0805 & & \\
\hline
\end{tabular}

In contrast to Sesarma reticulatum and Uca spp. larvae, first instar Dyspanopeus sayi larvae were as common during nocturnal spring ebb tide as nocturnal neap ebb tide. Moreover, transport from Flax Pond may have been slowed by tidal vertical migrations. During nocturnal ebb tides, D. sayi larvae were most abundant near the bottom, where bottom friction would slow ebb currents, and they occurred near the surface during nocturnal spring flood tide where strong flood currents would transport larvae into Flax Pond. Of the few $D$. sayi larvae that were collected during the daytime, most occurred near the bottom, which may have further slowed dispersal from the marsh while reducing the visibility of larvae to fishes.

More first instar larvae of the study species were exported from Flax Pond during nocturnal spring ebb tide $(97.7 \pm 0.9 \%)$ than during nocturnal neap ebb tide 

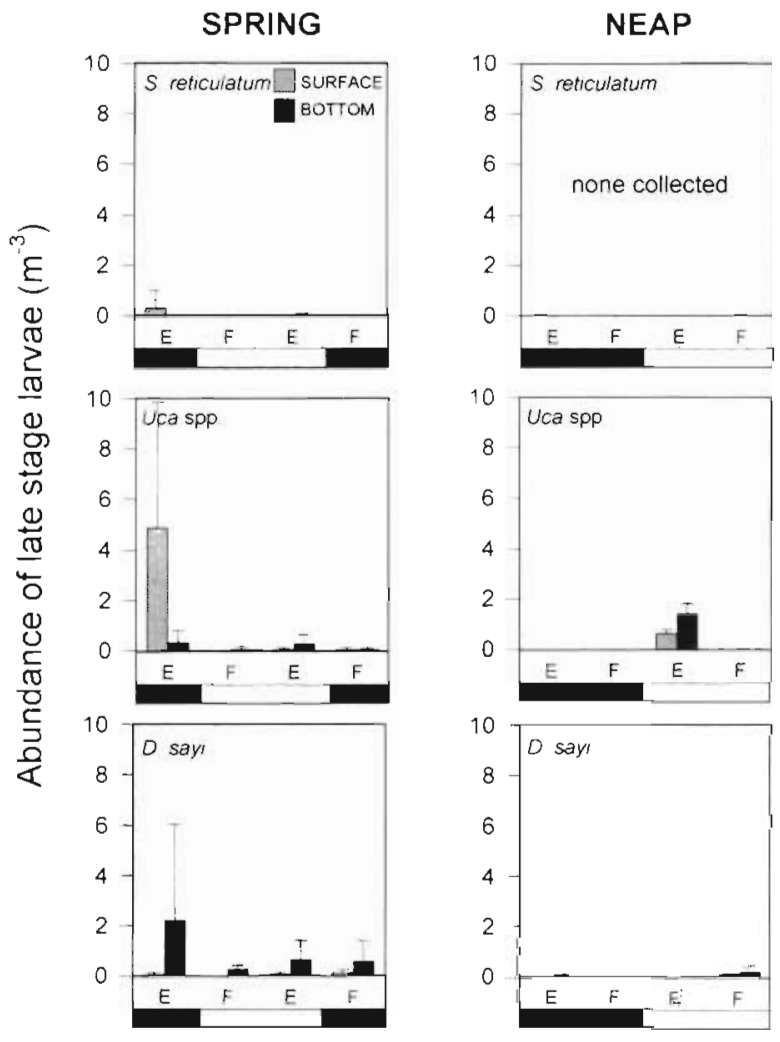

Tide

Fig. 6. Sesarma reticulatum, Uca spp. and Dyspanopeus sayi. Mean number $( \pm 1 \mathrm{SE}$ ) of late stage larvae near the surface $(0.25 \mathrm{~m}, \mathrm{n}=6)$ and bottom $(2.5 \mathrm{~m}, \mathrm{n}=6)$ of Flax Pond during $72 \mathrm{~h}$ long plankton surveys conducted during spring (August 22 to 25, 1994) and neap (August 28 to 31, 1994) tides. F: flood; E: ebb; dark bars: night; open bars: day

$(84.5 \pm 4.4 \%)(H=7.28 ; \mathrm{df}=1,1 ; \mathrm{p}=0.007)$. First instar Sesarma reticulatum and $U_{c a}$ spp. larvae were exported from the marsh more efficiently than were first instar larvae of Dyspanopeus sayi. During nocturnal spring ebb tide, $98.0 \%( \pm 1.7)$ of first instar $S$. reticulatum larvae and $99.9 \%( \pm 0.05)$ of first instar Uca spp. were exported, whereas $95.6 \%( \pm 2.2)$ of first instar $D$. sayi larvae were exported $(H=5.21 ; \mathrm{df}=1,2 ; \mathrm{p}=$ 0.070). During nocturnal neap ebb tide, $86.0 \%( \pm 9.2)$ of first instar $S$. reticulatum larvae and $87.5 \%( \pm 4.6)$ of first instar UCa spp. were exported, whereas only $58.2 \%( \pm 11.9)$ of first instar $D$. sayi larvae were exported $(H=6.31 ; \mathrm{df}=1,2 ; \mathrm{p}=0.046)$. Thus, first instar larvae of all study species were flushed almost entirely from Flax Pond by strong spring ebb currents at night, and transport of $D$. sayi larvae was especially effective at this time.

Perhaps due to the scarcity of late stage larvae, only 1 significant difference in their abundance was detected (Fig. 6, Table 6). Dyspanopeus sayi larvae
Table 6. Four-way ANOVA of late stage larvae of Sesarma reticulatum, Uca spp. and Dyspanopeus sayi collected in plankton tows relative to the tidal amplitude (Amplitude), tidal (Tide), and light-dark (Diel) cycles at 2 depths (Depth). p $<0.05, \cdots p<0.01, \cdots p<0.001$

\begin{tabular}{|lrrrc|}
\hline Source & df & MS & $F$ & $p$ \\
\hline Sesarma reticulatum & & & & \\
Amplitude & 1 & 0.0825 & 2.3096 & 0.132 \\
Tide & 1 & 0.0587 & 1.6437 & 0.203 \\
Diel & 1 & 0.0428 & 1.1979 & 0.277 \\
Depth & 1 & 0.0106 & 0.2979 & 0.586 \\
Error & 76 & 0.0331 & & \\
& & & & \\
Uca spp. & & & & \\
Amplitude & 1 & 2.8610 & 2.8610 & 0.094 \\
Tide & 1 & 2.1517 & 2.1517 & 0.146 \\
Diel & 1 & 2.0508 & 2.0508 & 0.156 \\
Depth & 1 & 8.0481 & 2.6087 & 0.110 \\
Error & 76 & 3.2938 & & \\
& & & & \\
Dyspanopeus sayi & & & & \\
Amplitude & 1 & 5.2345 & 4.6362 & 0.034 \\
Tide & 1 & 0.8667 & 0.7676 & 0.383 \\
Diel & 1 & 1.0423 & 0.9231 & 0.339 \\
Depth & 1 & 4.2753 & 3.7866 & 0.055 \\
Error & 76 & 1.0798 & & \\
\hline
\end{tabular}

were significantly more abundant during spring than neap tide, and they were marginally $(p=0.055)$ more abundant near the bottom than the surface of the water column, which may have reduced flushing from the marsh. In addition, Sesarma reticulatum larvae were collected only during ebb tides, when Uca spp. larvae also tended to be most common, suggesting that late stage larvae of these 2 species were flushed from Flax Pond. There also was a tendency for U/ca spp. larvae to be most abundant during nocturnal ebb tides and higher in the water column during nighttime than daytime. This suggests that $U_{C a}$ spp. larvae occurred near the bottom during the daytime and rose into the water column at night, especially during nocturnal ebb tides, which would both reduce visibility of larvae to fishes and enhance transport from Flax Pond.

Megalopae of Uca spp. and Dyspanopeus sayi were collected almost exclusively at night (Fig. 7, Table 7) Peak abundance of $U_{C a}$ spp. megalopae occurred during nocturnal spring flood tide, and the same trend $(\mathrm{p}=$ 0.075 ) was evident for $D$. sayi megalopae.

\section{Timing of recruitment}

Megalopae that settled on collectors included Sesarma reticulatum, Uca spp., Dyspanopeus sayi, Ovalipes ocellatus, Libinia emarginata and Panopeus herbstii 

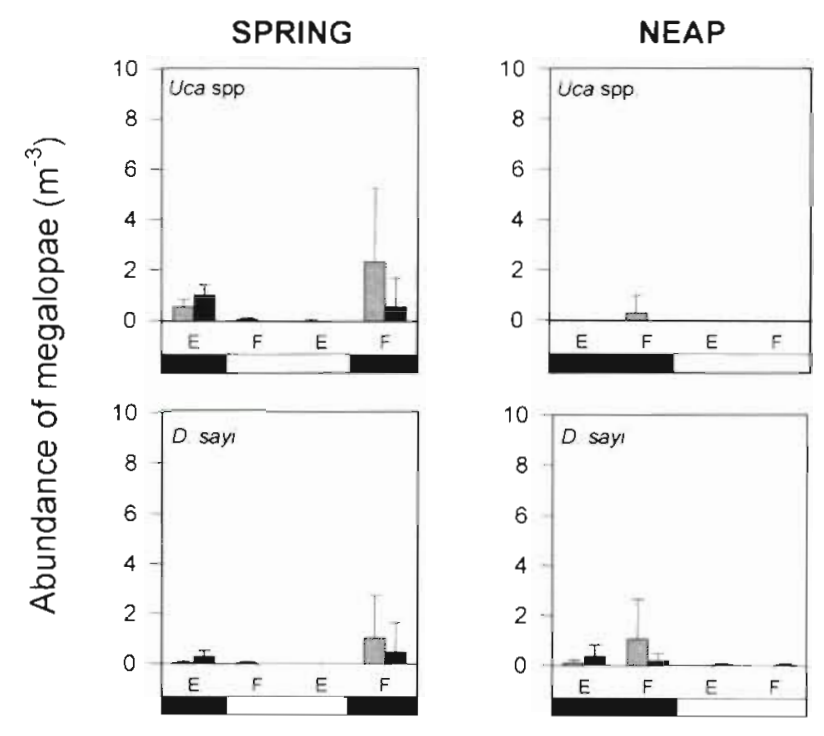

Tide

Fig. 7 Ucaspp. and Dyspanopeus sayi. Mean number ( \pm 1 SE) of megalopae near the surface $(0.25 \mathrm{~m}, \mathrm{n}=6)$ and bottom $(2.5 \mathrm{~m}, \mathrm{n}=6$ ) of Flax Pond, during $72 \mathrm{~h}$ long plankton surveys conducted during spring (August 22 to 25, 1994) and neap (August 28 to 31, 1994) tides. F: flood; E: ebb; dark bars: night; open bars: day

(Table 4). S. reticulatum, Uca spp. and D. sayi comprised $97.81 \%$ of the megalopae collected. S. reticulatum and $D$. sayi megalopae were most abundant $1 \mathrm{~d}$ after spring tides (Fig. 4 ; S. reticulatum: $\pm 3.61 \mathrm{~d}, r=$ $0.27, \mathrm{p}<0.001, \mathrm{n}=56 ;$ D. sayi: $\pm 2.9 \mathrm{~d}, r=0.43, \mathrm{p}<$

Table 7 Four-way ANOVA for megalopae of Uca spp. and Dyspanopeus sayi collected in plankton tows relative to the tidal amplitude (Amplitude), tidal (Tide), and light-dark (Diel) cycles at 2 depths (Depth). $p<0.05, \cdots p<0.01, \cdots p<0.001$

\begin{tabular}{|lrrrc|}
\hline Source & df & \multicolumn{1}{c}{ MS } & \multicolumn{1}{c|}{$F$} & $\mathrm{p}$ \\
\hline Uca spp. & & & & \\
Amplitude & 1 & 0.0962 & 0.0847 & 0.772 \\
Tide & 1 & 0.4106 & 0.4106 & 0.523 \\
Diel & 1 & 21.4730 & 18.9050 & $<0.001 \cdots$ \\
Depth & 1 & 1.0674 & 0.9398 & 0.335 \\
Tide $\times$ Amplitude & 1 & 5.8958 & 5.1906 & $0.025^{\circ}$ \\
Tide $\times$ Amplitude $\times$ Diel & 1 & 7.0643 & 6.2193 & $0.015 \cdot$ \\
Error & 76 & 1.1185 & & \\
& & & & \\
Dyspanopeus sayi & & & & \\
Amplitude & 1 & 0.0034 & 0.0078 & 0.930 \\
Tide & 1 & 0.0383 & 0.0875 & 0.768 \\
Diel & 1 & 4.4161 & 10.0840 & $0.002 \cdots$ \\
Depth & 1 & 1.2574 & 2.8712 & 0.094 \\
Tide $\times$ Amplitude & 1 & 1.3120 & 2.9960 & 0.087 \\
Tide $\times$ Amplitude $\times$ Diel & 1 & 1.4188 & 3.2398 & 0.075 \\
Error & 76 & 0.4582 & & \\
\hline
\end{tabular}

$0.001, \mathrm{n}=858$ ). The timing of peak recruitment by Uca spp. occurred $3 \mathrm{~d}$ before spring tides $( \pm 3.6 \mathrm{~d}, r=$ $0.28, \mathrm{p}<0.001, \mathrm{n}=154$ ) and differed from the other 2 species (Watson-Williams, $F=140.32$, df $=1,1065, \mathrm{p}<$ $0.001)$.

\section{Fish assemblage}

Planktivorous fishes were abundant in Flax Pond. In 4 seinings, 4395 fishes were collected for an average of nearly 1100 fishes per seine. Except for 2 individuals of Syngnathus spp., only Menidia menidia (2966), Fundulus majalis (1046) and F. heteroclitus (381) were captured. Variances were high because species composition and size varied with location and tidal phase (see Hovel 1995). Most $M$. menidia collected were 30 to $50 \mathrm{~mm}$ long, but fish smaller than $30 \mathrm{~mm}$ were not caught efficiently by the $6 \mathrm{~mm}$ mesh of the seine (Fig, 8). Most $F$. heteroclitus and $F$. majalis collected were less than $60 \mathrm{~mm}$ long. Therefore, the size classes of fishes used in predation experiments were among the most common ones in Flax Pond.
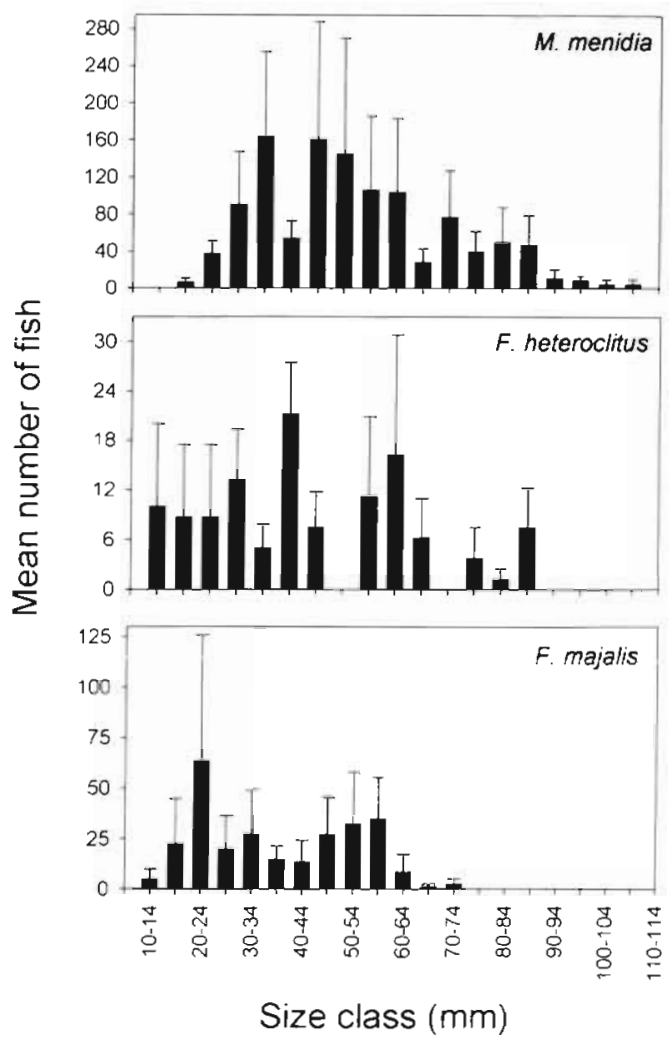

Fig. 8. Menidia menidia, Fundulus heteroclitus and F. majalis. Abundance and standard lengths caught in seines $(n=4)$ during August 1994 in Flax Pond 


\section{DISCUSSION}

Our data are consistent with the predictions of the predator avoidance hypothesis indicating that reproductive synchrony by shallow water crabs and rapid dispersal of their newly hatched larvae from parental habitats has evolved in response to predictable temporal and spatial variation in fish predation. Larvae of all 3 species were eaten by 2 of the dominant fishes in the marsh during predation experiments, and they hatched under the cover of darkness whereupon ebb tides transported them away from dense populations of these fishes into the deeper waters of Long Island Sound. Moreover, the most vulnerable larvae to predation were released most synchronously with maximum amplitude tides when larvae were transported from the marsh most effectively. Silversides and killifish both ate more Uca pugnax and Sesarma reticulatum larvae, which released larvae more synchronously with NMAHT and were transported from the marsh more effectively than were Dyspanopeus sayi larvae. Thus, predation rates were related to reproductive synchrony and the efficiency of larval dispersal from the marsh in accordance with the predator avoidance hypothesis.

\section{Feeding preferences of planktivorous fishes}

Variation in larval traits and predator size may explain interspecific differences in the vulnerability of larvae to predation. Spine length clearly affected predation by both silversides and killifish, because long spined Dyspanopeus sayi larvae were eaten less often than were short spined Sesarma reticulatum and Uca pugnax larvae (see Table 1). The long spines of D. sayi make these larvae more difficult to swallow (Morgan 1987 a, 1989, 1990). However, spines were less effective at deterring predation by large fishes, because these gape limited predators handle and ingest crab larvae more easily as mouth size increases (Morgan 1987 a, 1989, 1990). Killifish ate more crab larvae of all 3 species than did silversides, because their large mouths enabled them to handle armored prey better (Morgan 1987a, 1989, 1990).

The large bodies of Sesarma reticulatum larvae were effective at deterring predation by small silversides, which ate fewer of these larvae than small bodied Uca pugnax larvae. However, body size was ineffective at deterring predation by medium and large silversides and both size classes (>20 mm long) of killifish used in our study. Similar results have been obtained for silversides before (Morgan 1987a), but in addition, our study showed that large silversides preferred $S$. reticulatum larvae to $U$. pugnax larvae. This is consistent with the well-known tendency of planktivorous fishes to switch to the largest manageable and most conspicuous prey (O'Brien 1979, Zaret 1980. Lazarro 1987), but it is not consistent with an extensive study of the feeding preferences of both silversides and anchovies in natural populations. Morgan (1990) found that these fishes ate Uca spp. larvae as they were encountered but strongly avoided $S$ reticulatum larvae. In addition, long spined larvae (Rhithropanopeus harrisii) were almost entirely avoided. Fishes were surrounded by and their guts were packed with copepods and many other types of prey, indicating that these fishes were well fed. We suggest that the common practice of starving fish the day before feeding trials to standardize hunger levels may skew the feeding preferences of fishes toward large less manageable prey. Starved planktivorous fishes may be more attracted to and spend more time handling large difficult prey than they would otherwise, especially compared to fishes feeding in productive habitats where alternative prey abound. Our feeding experiments were designed to offset this tendency by offering fish abundant alternative prey and allowing them to feed for several hours without consuming more than $80 \%$ of their prey. However, the discrepancies between the feeding preferences of starved fishes in our predation experiments and well-fed fishes in the field suggests that fishes should not be starved the day before experiments to better simulate feeding by fishes in natural populations. Instead, fishes should be fed an overabundance of prey before experiments begin to both standardize hunger and more closely approximate the hunger level of fishes in productive aquatic habitats.

Thus, feeding preferences of these planktivorous fishes and survival of larvae primarily was determined by spine length; fishes preferred short spined Sesarma reticulatum and Uca spp. larvae to long spined Dyspanopeus sayi larvae. The large bodies of $S$. reticulatum also were effective at deterring predation by small silversides and may deter larger fishes when alternative prey are abundant, as is normally the case for larvae released in productive estuaries. There is little clear evidence of interspecific differences in the conspicuousness of these larvae to fishes, although Morgan \& Christy (1996) previously showed that larval conspicuousness can be more important than spine length in determining prey preferences of silversides. All of the larvae in our study were colored similarly by melanophores, whereas those in Morgan \& Christy's (1996) study were distinctively colored red, green, yellow and brown. Therefore, the greater contrast in larval colorations undoubtedly had a much stronger influence on prey choice than in the present experiment. 


\section{Impact of planktivory on reproductive synchrony and larval migration}

The feeding habitats of fishes clearly were related to reproductive timing by crabs. Larvae of all study species were eaten by fishes and were released only at night when planktivorous fishes do not feed (Hobson \& Chess 1978, Zaret 1980, Lazarro 1987, Morgan 1990). Larval release by these species also peaked when strong ebb currents transported larvae from parental populations most effectively, as previously proposed (Christy 1982, Salmon et al. 1986, Morgan 1990, Morgan \& Christy 1995). Moreover, vulnerable Sesarma reticulatum and $U_{c a}$ spp. larvae were released more synchronously with maximum amplitude tides than were well-defended Dyspanopeus sayi larvae. As a consequence, larvae that were most vulnerable to predation by fishes were transported from the marsh most effectively. During nocturnal neap ebb tide, only $58.2 \%$ of first instar D. sayi larvae were exported from Flax Pond as compared to $86.0 \%$ of first instar S. reticulatum larvae and $87.5 \%$ of first instar Uca spp. This difference was small during nocturnal spring ebb tide when $97.7 \%$ of all of these larvae were flushed from Flax Pond, because strong currents exchange more than $80 \%$ of the high tide volume between Flax Pond and Long Island Sound at this time (Woodwell \& Pecan 1973, Woodwell et al. 1977). Less water is exchanged between the marsh and the sound during nocturnal minimum amplitude high tide, which accounts for the reduced larval transport then $(84.5 \%)$. It is unlikely that the depletion of larvae was due primarily to predation, because few larvae were collected even during neap flood tide at night when planktivorous fishes had not yet begun to feed. Larvae clearly were exported from Flax Pond and developed in deeper adjacent waters, because only $0.37 \%$ of larvae collected in the marsh were late stage (second to final larval stage) larvae. Thus, the 4 most abundant species of crabs in Flax Pond avoided predation by planktivorous fishes in time and space by releasing larvae during NMAHT, and the 3 most vulnerable species were transported from the marsh most effectively.

The effectiveness of reproductive synchrony at reducing predation by natural populations of fishes in marshes was shown by Morgan (1990). Killifishes only live along shorelines and crab larvae that are released there were rare or absent from the diets of these fishes. Our study revealed that killifishes readily eat crab larvae, and therefore it is likely that few larvae were available to these fishes due to the rapid transport of larvae from shorelines. Anchovies and silversides occur in deeper waters where crab larvae develop, and as a consequence more larvae were eaten by these fishes. However, these fishes generally preferred less well-defended zooplankters. Thus, larvae largely may avoid predation by planktivorous fishes until they reach deeper waters where encounter rates would be reduced and conspicuous clouds of siblings would have diffused. Thereafter, larval defenses of most species are effective at deterring predation by fishes in productive estuaries

The timing of larval release may best be determined by holding ovigerous crabs in the laboratory or in boxes anchored in the field (Christy 1986, Morgan \& Christy 1994, 1995, Morgan 1996) rather than by sampling plankton. Of the 3 species held in the laboratory during our study, Sesarma reticulatum released larvae most synchronously relative to the tidal amplitude cycle, but this trend was marginally nonsignificant ( $\mathrm{p}=$ 0.07 ) in Flax Pond. The trend probably would have been significant if $S$. reticulatum were more abundant in the marsh. S. reticulatum comprised only $0.64 \%$ of all larvae collected in Flax Pond making it difficult to distinguish the pulse of larvae released during NMAHT from the background population of larvae that were already developing there. In contrast Uca spp., the most abundant crabs in Flax Pond comprising $90.87 \%$ of larvae collected, released a pulse of larvae that was orders of magnitude greater than the background population even though larval release was less synchronous in the laboratory. The presence of background concentrations of larvae in the plankton also may have obscured the weak synchrony in hatching relative to the tidal amplitude cycle shown by Dyspanopeus sayi in the laboratory; similar numbers of first instar D. sayi larvae occurred in the plankton during spring and neap ebb tide at night. Synchrony relative to the tidal amplitude cycle by this species is weak at best, because DeVries \& Forward (1989) found that $D$. sayi larvae were released asynchronously with respect to this environmental cycle

In addition to reproductive timing, vertical migrations by larvae may have affected the rate of transport from Flax Pond. Uca spp. larvae may have been transported from the marsh more rapidly than Sesarma reticulatum larvae, because they primarily occurred in fast-ebbing surface currents at night soon after they were released rather than occurring throughout the water column as $S$. reticulatum larvae did. However, export of remaining larvae may have slowed during daytime ebb tides because Uca spp. larvae remained close to the bottom where friction likely slowed ebb currents. Uca spp. larvae did not ascend during flood tides and therefore did not appear to undertake tidal vertical migrations; rather, they likely undertook diel vertical migrations by descending to the bottom of Flax Pond in response to light. In contrast, both tidal and ontogenetic vertical migrations may have slowed transport of Dyspanopeus sayi larvae from Flax Pond. 
Early D. sayi larvae occurred near the surface during flood tides and near the bottom during ebb tides at night, and late stage larvae mostly remained in bottom waters.

Diel, tidal and ontogenetic vertical migrations have been described for these species in primary and secondary estuaries that were not always evident in Flax Pond (Pinschmidt 1963, Sandifer 1975, Lambert \& Epifanio 1982, Epifanio et al. 1988, Morgan 1990, Kunze 1995, Schell 1996), because most newly released larvae were swiftly carried away by strong ebb currents at night. As a consequence, very few larvae were present during the daytime, during flood tides and later in development, making it difficult to determine whether or not their vertical distributions changed relative to diel and tidal cycles and ontogeny. Nevertheless, interspecific differences in larval behaviors do contribute to the differential transport of larvae between adult and larval habitats (reviewed by Morgan 1995b). Even though adults co-occur, Sesarma reticulatum and Dyspanopeus sayi larvae primarily develop within estuaries and Uca spp. primarily develop in nearshore coastal waters (Sandifer 1975, Epifanio et al. 1988, Morgan 1990, Kunze 1995, Matthews 1995, Lobue 1996, Schell 1996). Uca spp. and other species releasing small, short spined, vulnerable larvae may develop in deeper coastal waters where the densities of planktivorous fishes may be reduced, whereas large or long spined larvae develop entirely within estuaries despite initial seaward transport from shorelines (Morgan 1987a, b, 1990j. Hence, dispersal from estuaries may depend on the vulnerability of larvae to predation as does dispersal from marshes and other productive shallow water habitats. Larvae of all shallow water crabs studied thus far initially disperse from these high-risk habitats (reviewed by Morgan 1995a, Morgan \& Christy 1997), and those that are most vulnerable to predation continue to disperse offshore where planktivorous fishes may be encountered less often than in estuaries (Morgan 1987a, b, 1990).

Megalopae immigrate back up estuaries during nocturnal flood tides, especially during maximum amplitude flood tides (reviewed by J. H. Christy \& S. G. Morgan unpubl.). Our study has shown that recruitment to adult habitats also occurs at this time. Selective swimming at night and resting on the bottom during the daytime may minimize predation on megalopae as they migrate up-estuary and into marshes. Recruiting to marshes during maximum amplitude flood tides also may reduce predation, because megalopae would be transported most quickly and effectively through high densities of fishes to adult habitats. Megalopae do largely appear to avoid predation because an extensive study showed that few of them were eaten by the common planktivorous fishes (anchovies, silversides, killifishes) inhabiting Atlantic coast estuaries (Morgan 1990, but see Johnson et al. 1990).

Peak recruitment occurred biweekly near maximum amplitude tides throughout the entire reproductive season, because strong currents probably passively transported more megalopae into Flax Pond at this time (Woodwell \& Pecan 1973, Woodwell et al. 1977). The study species all develop in less than 1 mo (Chamberlain 1957, Costlow \& Bookhout 1962, Christy 1989), and therefore peak recruitment occurred about 2 or $4 \mathrm{wk}$ after larvae were released synchronously during NMAHT. The regular biweekly pulses in larval release and recruitment suggest that megalopae recruited reliably to Flax Pond and that reproduction and recruitment may be coupled. Moreover, the rank order of the number of first instar larvae and megalopae collected from the plankton was the same, which further suggests that megalopae recruited reliably to Flax Pond. Because Sesarma reticulatum and Dyspanopeus sayi larvae primarily develop in estuaries (Sandifer 1975, Morgan 1990, Kunze 1995, Matthews 1995, Lobue 1996, Schell 1996), most recruits to Flax Pond probably originated from populations in Long Island Sound. However, Uca spp. megalopae may or may not have come from local populations, because they primarily develop on the continental shelf where prevailing currents may transport larvae southward (Matthews 1995). Despite interspecific differences in the distances that larvae disperse from adult populations and the possible origins of larvae, the regular and reliable recruitment of all study species to Flax Pond suggests that reproductive and larval behaviors largely overcame mortality during the planktonic phase of the life cycle and coupled production to recruitment. This is in distinct contrast to the prevailing view that production and recruitment are decoupled in marine animals due to extensive larval mortality and advection (reviewed by Lafferty \& Gaines 1995, Caley et al. 1996, but see Yoshioka 1986, Robertson et al. 1988, Morgan 1995b).

Slight differences in the timing of recruitment relative to the tidal amplitude cycle by Uca spp. and the other 2 study species may have been due to variation in larval development times. Peak larval release by all of the study species occurred near maximum amplitude tides but most Uca spp. megalopae recruited to Flax Pond $2 \mathrm{~d}$ before Sesarma reticulatum and $4 \mathrm{~d}$ before Dyspanopeus sayi. Uca spp. molt through 5 larval stages and 1 megalopa stage in about 3.5 to $4 \mathrm{wk}$ at 22 to $24^{\circ} \mathrm{C}$ (Christy 1989), which is consistent with peak recruitment occurring $3 \mathrm{~d}$ before NMAHT at the temperatures of Flax Pond. The other 2 study species have fewer larval stages [S. reticulatum has 3 (Chamberlain 1957) and $D$. sayi has 4 (Costlow \& Bookhout 1962)] and may have recruited to Flax Pond only $2 \mathrm{wk}$ 
after hatching. S. reticulatum and $D$. sayi larvae reared in the laboratory have required about 2.5 and $3 \mathrm{wk}$ to complete development (Chamberlain 1957, Costlow \& Bookhout 1962), but we suggest that larval development time in the plankton is faster Christy (1989) was able to rear Uca spp. larvae to the first crab stage much faster than were previous investigators by providing appropriate substrate for settlement, and improved rearing techniques also may reduce rearing times of $S$. reticulatum and $D$. sayi.

Fewer Uca spp. megalopae settled on passive collectors all summer than were captured in the plankton during $1 \mathrm{wk}$, indicating that the collectors underestimated the number of $U_{c a} \mathrm{spp}$. megalopae recruiting to adult populations. Cues from sediment, algae or adults may induce megalopae to settle preferentially on the shore rather than on collectors (see Christy 1989, Jensen 1989, Forward et al. 1996, Morgan et al. 1996).

\section{Alternative hypotheses}

Predation on adults partially may select for the timing of larval release and indirectly affect dispersal from shorelines. Predators may eat ovigerous female crabs or attached embryos as they emerge from burrows to release larvae. Releasing larvae during NMAHT may enable females to release larvae near refuges under the cover of darkness (Morgan 1990, Morgan \& Christy 1995). Species that live high on the shore can only release larvae when their burrows are inundated by maximum amplitude tides, whereas species living low on the shore may release larvae from burrows during any high tide. Of the study species, Sesarma reticulatum lives highest on the shore and Dyspanopeus sayi lives lowest on the shore, which may explain the high and low synchrony of larval release by these species with maximum amplitude tides, respectively. However, D. sayi and Uca pugnax burrows are immersed by all high tides, and therefore these species could release larvae asynchronously relative to the tidal amplitude cycle. That they do not clearly suggests that reproductive timing is determined more by predation on larvae than on adults or embryos.

Other selective pressures do not adequately explain why larvae of so many crabs are released during NMAHT and are transported rapidly from marshes. Unlike fishes, invertebrates do not feed primarily during the daytime, occur in predictably high densities in marshes or appear to be important predators of crab larvae (Morgan 1992, 1995a). Damage from ultraviolet- $B$ radiation (UVBR) is unlikely to be an important selective factor in marshes because larvae of our study species tend to avoid surface waters during the daytime. Moreover, larval mortality of these species increased only after larvae were held just beneath the surface for several consecutive bright sunny days (Hovel 1995). Morgan \& Christy (1996) also concluded that UVBR did not affect the timing of larval release in the tropics where UVBR intensities have been greatest historically.

Physiological stress from high temperatures and low salinities does not appear to be an important selective factor even though freshwater runoff and heating during low tide may rapidly alter the salinity and temperature of the water in marshes (Dollard 1980, Saigusa 1981). Uca minax larvae, which are released in marshes, survived exposure to extreme temperatures and salinities in the laboratory better than did Rhithropanopeus harrisii larvae, which typically are released in primary estuaries (Morgan 1987b). Furthermore, crabs that live along open coastlines where temperature and salinity vary little also release larvae during NMAHT (Christy 1986, Morgan \& Christy 1994, 1995).

Finally, larval release during spring tides does not appear to facilitate the return of larvae to adult habitats weeks later, because peak recruitment by Uca spp. megalopae does not always occur at this time (Christy 1982). The timing of peak recruitment may be determined more by larval development time and the strength of flood currents transporting megalopae to adult habitats.

\section{Conclusion}

Predation may be one of the strongest selective forces shaping the lives of estuarine crabs. Ovigerous females and their offspring are especially vulnerable to predators, and therefore compensatory traits may be most evident during reproduction and larval development. Planktivorous fishes may have a particularly profound impact on the early life histories of crabs, because most of them feed in a similar manner and foraging is predictable in time and space. These gape limited predators primarily feed during the day and densities are highest in productive marshes and mangroves. Hence, all species of crabs living in such habitats release larvae at night when ebb currents, and especially strong ebb currents, transport larvae away from these habitats before dawn while siblings diffuse from one another (reviewed by Morgan 1995a, Morgan \& Christy 1997). The rate of dispersal from these habitats and the degree to which larvae continue to disperse from estuaries apparently depends on the vulnerability of larvae to fish predation. Differential horizontal migrations require different suites of reproductive and larval traits. Species that develop in estuaries appear to invest more energy per offspring, produce fewer larger eggs, release large well-defended larvae, develop 
quickly and undertake vertical migrations that favor larval retention; whereas the opposite suite of traits occurs in species that develop in safer offshore waters (Morgan 1990).

Regardless of whether larvae of estuarine crabs disperse to the continental shelf or not, megalopae of all species must return to adult habitats. Recruitment to Flax Pond occurred during flood tides, especially strong flood tides, at night when upstream transport is maximized and predation by fishes is minimized (reviewed by J. H. Christy \& S. G. Morgan unpubl.). Megalopae of all study species recruited regularly in the same relative proportions that they were released throughout the entire reproductive season, despite interspecific differences in the distances of larval migrations, which suggests that reproductive and larval behaviors largely overcame mortality during the planktonic phase of the life cycle and coupled production to recruitment. Thus, predictable variation in predation by planktivorous fishes exerts strong selective pressure on crabs that release larvae in productive shallow waters, and suites of reproductive and larval traits apparently have evolved that favor migration between adult and larval habitats.

Silversides and killifishes not only occur in high densities in Flax Pond but predominate in marshes all along temperate and tropical shorelines (Morgan 1986 , Sogard \& Abele 1991, Ayvazian et al. 1992, Rountree \& Able 1992, Sasekumar et al. 1992, Baltz et al. 1993). Therefore, crabs living in shallow waters likely experience similar predation pressures throughout their geographic ranges thereby providing strong selection for the evolution of predator avoidance behaviors. In addition to our study, several other investigations of the effects of fish predation on larval synchrony and migration now have been conducted along the Atlantic and Gulf coasts of the USA and in the Republic of Panama (Morgan 1987a, b, 1989, 1990, Morgan \& Christy 1997, S. G. Morgan \& S. T. McAfee unpubl.). All of these studies implicate planktivorous fishes as the primary selective agent favoring reproductive synchrony and larval migration between shallow water adult habitats and deeper safer larval habitats. However, it remains to be demonstrated that predation on crab larvae that fail to be flushed from these habitats is greater than it is in primary estuaries and coastal waters. This contrast would provide another critical test of the predator avoidance hypothesis of reproductive synchrony and larval migration.

Acknowledgements. We thank J. Anastasia, A. Matthews, C. Lobue, J. Schell and H. Kunze for their assistance in the field and $\mathrm{D}$. Conover and $\mathrm{R}$. Cowen for commenting on an earlier version of the manuscript. S. McAfee provided helpful comments on later versions of the manuscript. We also thank Sigma Xi. The Sounds Conservancy and the Hudson River
Foundation (grant 009-93A) for financial support. This research is in partial fulfillment of a Master of Science degree at the State University of New York at Stony Brook.

\section{LITERATURE CITED}

Ayvazian SG, Deegan LA, Finn JT (1992) Comparison of habitat use by estuarine fish assemblages in the Acadian and Virginian zoogeographic provinces. Estuaries 15:368-383

Baltz DM, Rakocinski C, Fleeger JW (1993) Microhabitat use by marsh-edge fishes in a Louisiana estuary. Environ Biol Fish 36:109-126

Brookins KG, Epifanio CE (1985) Abundance of brachyuran larvae in a small coastal inlet over six consecutive tidal cycles. Estuaries 8:60-67

Caley MJ, Carr MH, Hixon MA, Hughes TP, Jones GP, Menge BA (1996) Recruitment and the local dynamics of open marine populations. Annu Rev Ecol Syst 27:477-500

Chamberlain NA (1957) Studies on larval development of Neopanope texana sayi (Smith) and other crabs of the family Xanthidae (Brachyura). Chesapeake Bay Inst Johns Hopkins Univ Tech Rep 22:1-37

Chia FS, Buckland-Nicks J, Young CM (1984) Locomotion of marine invertebrate larvae: a review. Can J Zool 62: $1205-1222$

Christy JH (1982) Adaptive sighificance of semilunar cycles of larval release in fiddler crabs (Genus UCa): test of a hypothesis. Biol Bull Mar Biol Lab Woods Hole 163:251-263

Christy JH (1986) Timing of larval release by intertidal crabs on an exposed shore. Bull Mar Sci 39:176-191

Christy JH (1989) Rapid development of megalopae of the fiddler crab Uca pugilator over sediment: implications for models of larval recruitment. Mar Ecol Prog Ser 57:259-265

Christy JH, Stancyk SE (1982) Movement of larvae from North Inlet estuary, S.C. with special reference to crab zoeae. In: Kennedy V (ed) Estuarine comparisons. Academic Press, New York, p 489-510

Costlow JD Jr, Bookhout CG (1962) The larval development of Sesarma reticulatum Say reared in the laboratory. Crustaceana 4:281-294

Cronin TW, Forward RB Jr (1979) Tidal vertical migrations: an endogenous rhythm in estuarine crab larvae. Science 205: $1020-1022$

Cronin TW, Forward RB Jr (1986) Vertical migration cycles of crab larvae and their role in larval dispersal. Bull Mar Sci 39:192-201

DeCoursey P (1979) Egg hatching rhythms in three species of fiddler crabs. In: Naylor E, Hartnoll RG (eds) Cyclic phenomena in marine plants and animals. Proc 13th Eur Mar Biol Symp, Pergamon, Oxford, p 399-406

DeCoursey PJ (1983) Biological timing. In: Bliss DE (ed) The biology of Crustacea, Vol 7 Academic Press, New York, p $107-162$

DeVries MC, Forward RB Jr (1989) Rhythms in larval release of the sublittoral crab Neopanope sayi and the supralittoral crab Sesarma cinereum (Decapoda: Brachyura). Mar Biol 100:241-248

Dollard HA (1980) Larval release patterns in the wharf crab, Sesarma cinereum, from North Inlet, South Carolina. MSc thesis. University of South Carolina Columbia

Epifanio CE (1988) Transport of invertebrate larvae between estuaries and the continental shelf. Am Fish Soc Symp 3: $104-114$

Epifanio CE Little KT, Rowe PM (1988) Dispersal and recruitment of fiddler crab larvae in the Delaware River estuary. Mar Ecol Prog Ser 43:181-188 
Forward RB Jr (1987) Larval release rhythms of decapod crustaceans: an overview. Bull Mar Sci 41:165-176

Forward RB Jr (1988) Diel vertical migration: zooplankton photobiology and behaviour. Oceanogr Mar Biol Annu Rev 26:361-393

Forward RB Jr, DeVries MC, Rittschof D, Frankel DAZ, Bischof JP, Fisher CM, Welch JM (1996) Effects of environmental cues on metamorphosis of the blue crab Callinectes sapidus. Mar Ecol Prog Ser 1131:165-177

Gaines SD, Lafferty KD (1995) Modeling the dynamics of marine species: the importance of incorporating larval dispersal. In: McEdward L (ed) Ecology of marine invertebrate larvae. CRC Press, Boca Raton, FL, p 389-412

Hobson ES, Chess JR (1978) Trophic relationships among fishes and plankton in the lagoon at Enewetok atoll, Marshall Islands. Fish Bull 76:133-153

Hovel KA (1995) Predation and UV as selective agents promoting rapid transport of crab larvae through shallow marshes. MSc thesis, State University of New York, Stony Brook

Ims RA (1990) The ecology and evolution of reproductive synchrony. Am Nat 136:485-498

Jensen GC (1989) Gregarious settlement by megalopae of the porcelain crabs Petrolisthes cinctipes (Randall) and $P$ eriomerus (Stimpson). J Exp Mar Biol Ecol 131. $223-231$

Johannes RE (1978) Reproductive strategies of coastal marine fishes in the tropics. Environ Biol Fish 3:65-84

Johnson LE, Allen DM, Ogburn MV, Stancyk SE (1990) Shortterm predation responses of adult bay anchovies Anchoa mitchelli to estuarine zooplankton availability. Mar Ecol Prog Ser 64:55-68

Knieb RT, Stiven AE (1978) Growth, reproduction, and feeding of Fundulus heteroclitus (L.) on a North Carolina salt marsh. J Exp Mar Biol Ecol 31:121-140

Kunze HB (1995) Larval transport in the lower Hudson River esturary. MSc thesis, State University of New York, Stony Brook

Lambert R, Epifanio CE (1982) A comparison of dispersal strategies in two genera of brachyuran crab in a secondary estuary. Estuaries 5:182-188

Lazzaro X (1987) A review of planktivorous fishes: their evolution, feeding behaviours, selectivities, and impacts. Hydrobiologia 146:97-167

Little KT, Epifanio CE (1991) Mechanism for the re-invasion of an estuary by two species of brachyuran megalopae. Mar Ecol Prog Ser 68:235-242

Lobue C (1996) Depth regulation in larvae near the Hudson River plume front: implications for cross-front transport MSc thesis, State University of New York, Stony Brook

Matthews AE (1995) Cross-shelf transport of crab larvae in the New York Bight. MSc thesis, State University of New York, Stony Brook

McConaugha JR (1988) Export and reinvasion of larvae as regulators of estuarine decapod populations. Am Fish Soc Symp 3:90-103

McFall-Ngai MJ (1990) Crypsis in the pelagic environment. Am Zool 30:175-188

Morgan SG (1986) The impact of planktivorous fishes on the life histories of estuarine cabs. Doctoral dissertation. Unlversity of Maryland, College Park

Morgan SG (1987a) Morphological and behavioral antipredatory adaptations of decapod zoeae. Oecologia (Berlin) 73:393-400

Morgan SG (1987b) Adaptive significance of hatching rhythms and dispersal patterns of estuarine crab larvae avoidance of physiological stress by larval export? J Exp Mar Biol Ecol 113:71-78
Morgan SG (1989) Adaptive significance of spination in estuarine crab zoeae. Ecology 70:464-482

Morgan SG (1990) Impact of planktivorous fishes of dispersal, hatching, and morphology of estuarine crab larvae. Ecology 71:1639-1652

Morgan SG (1992) Predation by planktonic and benthic invertebrates on larvae of estuarine crabs. J Exp Mar Biol Ecol $163: 91-110$

Morgan SG (1995a) The timing of larval release. In: McEdward L (ed) Ecology of marine invertebrate larvae. CRC Press, Boca Raton, FL, p 157-192

Morgan SG (1995b) Life and death in the plankton: larval mortality and adaptation. In: McEdward L (ed) Ecology of marine invertebrate larvae. CRC Press, Boca Raton, FL, p 279-321

Morgan SG (1996) Influence of tidal variation on reproductive timing. J Exp Mar Biol Ecol 206:237-251

Morgan SG, Christy JH (1994) Plasticity, constraint, and optimality in reproductive timing. Ecology 77:2185-2203

Morgan SG, Christy JH (1995) Adaptive significance of the timing of larval release by crabs. Am Nat 145:457-479

Morgan SG, Christy JH (1996) Survival of marine larvae under the countervailing selective pressures of photodamage and predation. Limnol Oceanogr 41:498-504

Morgan SG, Christy JH (1997) Planktivorous fishes as selective agents for reproductive synchrony. J Exp Mar Biol Ecol 209:89-101

Morgan SG, Zimmer-Faust RK, Heck KL Jr, Coen LD (1996) Population regulation of blue crabs, Callinectes, in the northern Gulf of Mexico: postlarval supply. Mar Ecol Prog Ser 133:73-88

O'Brien WJ (1979) The predator-prey interaction of planktivorous fish and zooplankton. Am Scient 67:572-581

Peterson CH, Renaud PE (1989) Analysis of feeding preference experiments. Oecologia 80:82-86

Pinschmidt WC Jr (1963) Distribution of crab larvae in relation to some environmental conditions in the Newport River estuary, North Carolina. PhD dissertation, Duke University, Durham

Robertson DR, Green DG, Victor BC (1988) Temporal coupling of production and recruitment of larvae of a Caribbean reef fish. Ecology 69:370-381

Rountree RA, Able KW (1992) Fauna of polyhaline subtidal marsh creeks in southern New Jersey: composition, abundance and biomass. Estuaries 15:171-185

Saigusa M (1981) Adaptive significance of a semilunar rhythm in the terrestrial crab Sesarma. Biol Bull Mar Biol Lab Woods Hole 160:311-321

Salmon M, Seiple WH, Morgan SG (1986) Hatching rhythms of fiddler crabs and associated species at Beaufort, North Carolina. J Crustac Biol 6:24-36

Sandifer PA (1975) Distribution and abundance of decapod crustacean larvae in the York River estuary and adjacent lower Chesapeake Bay, Virginia, 1968-1969. Chesapeake Sci 14:235-257

Sasekumar A, Chong VC, Leh MU, D'Cruz R (1992) Mangroves as a habitat for fish and prawns. Hydrobiologia $247: 195-207$

Schell J (1996) Variation in the timing of vertical swimming by crab larvae in two tidal regimes. MSc thesis. State University of New York, Stony Brook

Seiple W (1979) Distribution, habitat preference and breeding periods in the crustaceans Sesarma cinereum and S. reticulatum (Brachyura: Decapoda: Grapsidae). Mar Biol 52: $77-86$

Sogard SM, Able KW (1991) A comparison of eelgrass, sea lettuce macroalgae, and marsh creeks as habitats for epiben- 
thic fishes and decapods. Estuar Coast Shelf Sci 33:501-519 Sokal RR, Rohlf FJ (1995) Biometry. WH Freeman, San Francisco

van Montfrans J, Epifanio CE, Knott DM, Lipcius RM, Mense DJ, Metcalf KS, Olmi EJ III, Orth RJ, Posey MH, Wenner EL, West TL (1995) Settlement of blue crab postlarvae in western North Atlantic estuaries. Bull Mar Sci $57: 834-854$

Werner EE, Hall DJ (1974) Optimal foraging and the size selection of prey by the bluegill sunfish (Lepomis macrochirus). Ecology 55:1042-1052

Wheeler DE (1978) Semilunar hatching periodicity in the mud fiddler crab Uca pugnax (Smith). Estuaries 1:268-269

Williams AB (1984) Shrimps, lobsters, and crabs of the

Editorial responsibility: Joseph Pawlik (Contributing Editor), Wilmington, North Carolina, USA
Atlantic coast of the eastern United States, Maine to Florida. Smithsonian Institution, Washington, DC

Woodwell GM, Pecan EV (1973) Flax Pond: an estuarine marsh. Brookhaven Natl Lab Tech Rep BNL 50397:1-7

Woodwell GM, Whitney DE, Hall CAS, Houghton RA (1977) The Flax Pond ecosystem study: exchanges of carbon in water between a salt marsh and Long Island Sound. Limnol Oceanogr 22:833-838

Yoshioka PM (1986) Chaos and recruitment in the bryozoan, Membranipora membranacea. Bull Mar Sci 39:408-417

Zar JH (1984) Biostatistical analysis. Prentice-Hall, Englewood Cliffs, $\mathrm{NJ}$

Zaret TM (1980) Predation and freshwater communities. Yale University, New Haven, CT

Submitted: May 15, 1996; Accepted: June 27, 1997

Proofs received from author(s): September 12, 1997 